Multimodal imaging을 통한 다초점맥락막염과 점상내측맥락막병증의 비교, 그리고 그 정의에 대한 고찰

\title{
Multifocal Choroiditis and Punctate Inner Choroidopathy through Multimodal Imaging: A Comment on the Present Nomenclature
}

\author{
강현승, 변석호 \\ Hyunseung Kang, Suk Ho Byeon \\ 연세대학교 의과대학 안과학교실 시기능개발연구소 \\ The Institute of Vision Research, Department of Ophthalmology, Yonsei University College of Medicine, Seoul, Korea
}

Multifocal choroiditis (MFC) has been defined as a disease characterized by multifocal choroidal inflammatory lesions occurring predominantly in young myopic women, idiopathic in origin, and not associated with any systemic disorder. However, there are numerous diseases that share similar features and definitions, such as "punctate inner choroidopathy (PIC)," complicating the differential diagnosis. Many of the present authors regard MFC and PIC to be the same disorder and include them under the single diagnosis "idiopathic MFC" regardless of the presence of ocular inflammation. In addition, there are many diagnostic terms that overlap or duplicate idiopathic MFC, again complicating the differential diagnosis. Recent advancement in technology has allowed a technique called 'multimodal imaging,' which has produced new findings about previously little-known diseases. These new findings have shown that many cases of what were diagnosed as idiopathic choroidal neovascularization (CNV) or myopic CNV were actually secondary to unrecognized MFC/PIC. In other words, the incidence of MFC/PIC was underestimated. Recent findings with multimodal imaging suggest a reappraisal of the pathophysiology of these diseases. Herein, we introduce recent reports of MFC/PIC based on multimodal imaging.

Keywords: Enhanced depth imaging OCT; Multifocal choroiditis; Multifocal choroiditis and panuveitis; Multimodal imaging; Punctate inner choroidopathy

\section{서론}

1973년에 Nozik and Dorsch가 presumed ocular histoplasmosis (POHS)와 비슷한 안저 병변(punched-out lesion)을 보이면서 전 방에 염증을 동반한 환자들을 보고하였고[1], 1984년도에 이르 러서야 현재 많이 사용하고 있는 "전체포도막염과 동반된 다초 점맥락막염(multifocal choroiditis with panuveitis, $\mathrm{MCP})$ "이라는 용어가 Dreyer and Gass에 의해 소개되었다[2]. 그들은 이 질환 이 맥락막의 병변과 더불어 전방 및 유리체의 염증이 동반된다 고 기술하였고 흔하게 재발하는 경향이 있다고 하였다. 같은 해에 Watzke et al. [3]이 전방 및 유리체 염증이 없으면서 흰노 란 점들이 위축성 반흔으로 진행하는 환자들을 보고하였는데,

\section{Address reprint requests to Suk Ho Byeon, MD, PhD}

Department of Ophthalmology, Yonsei University College of Medicine, \#50-1 Yonsei-ro, Seodaemun-gu, Seoul 03722, Korea

Tel: 82-2-2228-3570, Fax: 82-2-312-0541

E-mail: shbyeon@yuhs.ac
Received: 2016.8. 31

Revised: 2016. 9. 22

Accepted: 2016. 9.26 
비염증성이란 특징을 강조하듯 "점상내측맥락막병증(punctate inner choroidopathy, PIC)"이라고 명명하였다. 그들은 이 질환 이 근시와 연관이 있다고 보고 이런 병변이 락커칠 균열 타입의 맥락망막흥터일 것이라는 가설을 제안하였다. 하지만 병변이 지 속적으로 활동성을 띠며 재발을 반복하고 급성대상잠재외망막 병증(acute zonal occult outer retinopathy, AZOOR)으로 진행하 는 증례들까지 보고되면서 PIC도 결국 염증성 질환이라고 여겨 지게 되었다[3,4]. Multifocal choroiditis (MFC)/PIC는 유전적 감 수성을 가진 개인에게 발생하는 자가면역 질환의 눈 증상 중 하 나라고 설명되기도 하나, 그 원인병리론에 대해서는 아직 밝혀 진 바가 없다. 최근에는 $\mathrm{MFC} / \mathrm{PIC}$ 가 동일한 사이토카인 다형성 을 공유한다는 연구결과가 발표되면서 이 두 질환이 같은 질병 이라는 가설을 뒷받침하였다[5].

이 두 질환은 많은 유사성을 갖기 때문에 감별진단을 위해 그동안 앞포도막염 및 유리체염의 유무, 형광안저혈관조영술 (fluorescein angiography, FA) 양상, 그리고 안저검사상 병변의 크기 등을 비교해왔다. 하지만 시간이 흐르면서 맥락망막흥터 나 위축 병변이 점차 커지는 경우 크기만으로 이 둘을 분간해 내기가 불가능하고, 특히 근시안의 경우 병변의 크기 변화에 독 립적으로 영향을 미칠 수 있기 때문에 이러한 차이점은 감별에 큰 도움이 되지 않는다. 또한, MFC 자체가 비활동기에 접어든 상태에서는 앞포도막염 및 유리체염이 관찰되지 않기 때문에 $\mathrm{PIC}$ 와의 감별이 더욱 어려울 수 있다.

전통적으로 $\mathrm{MFC} / \mathrm{PIC}$ 의 진단검사법은 안저검사와 $\mathrm{FA}$ 정도 에 그쳤으나 그동안 컴퓨터 시스템에 기반한 이미지 분석기술 의 눈부신 발전에 힘입어 최근에는 multimodal imaging을 통해 모호한 경계를 갖는 질환들을 비교하고 이해하는 데 도움이 되 고 있다[6]. 본 연구에서는 $\mathrm{MFC} / \mathrm{PIC}$ 의 임상양상에 대해 살펴 보고, 최근 multimodal imaging을 이용한 연구 결과들을 통하 여 새롭게 정립되고 있는 질환에 대한 새로운 개념과 최신지견 에 대해 살펴보고자 한다.

\section{본론}

\section{임상양상}

$\mathrm{MFC} / \mathrm{PIC}$ 는 근시를 가진 젊은 건강한 여성에게 주로 발병하며 대부분 검사상 양안을 침범한 양상을 보이나 증상은 주로 단 안의 시력저하, 광시증, 비문증, 맹점확대로 나타난다. 염증 병 변이 황반부에 발생하거나 맥락막혈관신생이 동반될 때 중심시 력저하가 발생하게 된다. 병변은 50-1,000 $\mu \mathrm{m}$ 정도 크기로 안 저 전체에 퍼져있을 수 있으나 주로 후극부에서 적도부까지 위 치하며 유리체에 염증반응이 관찰될 수도 있다. 여러 개의 황 색 내지 회색의 병변들은 망막색소상피나 맥락막 내층에 위 치하며 시간이 지나 염증이 가라앉으면 위축된 과색소 병변 (punched-out)으로 남는다. POHS에서 보이는 시신경 주위 색 소변화(peripapillary scarring)도 관찰되는 것이 특징이다. 풍토 지역은 없으며 histoplasmin skin test에 대한 양성률은 매우 낮 다. 낭포황반부종이 15-40\%까지 보고되었으며, 약 25\%에서 황 반부에 망막하 신생혈관이 발생한다. 단순히 맹점확대를 보이 거나 경미한 시신경 부종이 관찰되기도 하는데 이것은 아마도 시신경유두 주변부의 망막 기능장애(peripapillary retinal dysi function) 때문이라고 생각된다. 때때로 안저 소견과 일치하지 않는 커다란 시야결손이 나타나기도 하는데 이것은 광수용체 의 특정 부분이 급성 손상을 입은 결과라고 추정된다. 한 구역 이거나 여러 개의 작은 구역일 수 있으며 주로 시신경유두 주위 이거나 망막 주변부의 큰 영역을 침범한다. 이러한 큰 영역의 망 막 수용체 손상은 결국 망막혈관의 가늘어짐과 망막색소상피의 변질을 일으키면서 망막색소변성증과 같은 형상을 띠기도 한다. 이렇듯 MFC/PIC의 '휴지기'에는 AZOOR, Multiple evanescent white dot syndrome (MEWDS), acute idiopathic blind-spot enlargement (AIBSE)와 같은 질환들과 매우 흡사하기에 이 모두 를 통틀어 AZOOR complex disorder라고 분류하기도 한다[7,8].

\section{검사소견}

병력청취상 감기유사증세가 있을 수 있다. 이 질환이 바이러스 에 의한 것이라는 가설이 소개되었는데, Epstein-Barr virus 등 에 대한 $\operatorname{IgM}, \operatorname{IgG}$ 등이 발견된다고 하였고 헤르페스 바이러스 의 가능성도 제시되었으나 아직 조직생검상 바이러스가 발견된 적은 없다[9]. 이 질환은 원래 일차적인 원인 질환이 없는 경우 진단 내릴 수 있기 때문에 여러 가지 감염성 질환, 예를 들면 결 핵, brucellosis, 사르코이도시스 혹은 기타 진균감염에 의해서 도 비슷한 양상을 나타내는 경우들이 있어 정밀검사가 필요하 다. FA상 병변은 초기에 저형광으로 시작해 점차적으로 채워지 다가 후기에는 누출이 일어나고, punched-out lesion은 전형적 인 창문비침을 보이다가 후기에는 흐려진다(fuzzy leakage). 인 도시아닌그린혈관조영(indocyanine green angiography, ICGA)에 서 병변은 지속적인 저형광으로 보이며 종종 안저 검사나 $\mathrm{FA}$ 에 서 보이는 것보다 더 많은 수의 병변이 관찰되는데, 이는 시야 결손과 관련이 있다고 알려져 있다. 전기생리학적 검사에서 특 징적인 소견은 보이지 않는다.

\section{감별진단}

$\mathrm{MFC}$ 와 유사한 망막소견을 보이는 질환으로는 결핵, 사르코이 도시스, brucellosis, coccidiomycosis, 칸디다증, 그 밖의 다른 granulomatous disease (Blau syndrome) 등이 있을 수 있다. 이러 한 점에서 Spaide et al. [10]은 POHS를 포함시킨 이차성 병변을 아우르는 이름으로 'MFC spectrum'이라는 명칭을 사용하기도 한다. $\mathrm{POHS}$ 에 대해서는 사실상 임상양상이나 표현형은 $\mathrm{MFC/}$ $\mathrm{PIC}$ 와 거의 같다고 보이지만, 그래도 따로 분류하는 것이 좋겠 
다. POHS는 미국에서 histoplasma가 풍토질환인 특정한 지역 에서 발현되고 남성과 여성이 거의 비슷한 비율로 다소 늦은 나 이에 발생하며 근시와 무관하게 진행하고 재발이 드물다는 점 등이 다른 질환으로 인정할 만한 특징들을 갖고 있다 (Fig. 1).

\section{Multimodal Imaging을 통해 제시된 MFC/PIC에 대한 새로운 개념들}

2013년 Spaide et al. [10]은 기존의 정형화된 진단기준에 의거하 여 진단된 $\mathrm{MCP} / \mathrm{PIC}$ 환자 22명 38안을 대상으로 후향적 관찰 연구를 진행하였으며 multimodal imaging-컬러 안저사진, FA, 자가형광안저촬영(fundus autofluorescence, FAF), 스펙트럼영역 빛간섭 단층촬영(spectral domain optical coherence tomography, SD-OCT)-을 통해 관찰된 각 질환의 맥락망막 병변이 거 의 같은 양상을 보인다고 보고하였다. 본 연구에 따르면 급성의 병변은 망막색소상피 아래로 결절성의 저류로 나타났다. 그리 고 그러한 고형의 망막색소상피박리들은 파열되면서 외층망막 이나 망막하 공간으로 염증성 침윤이 발생하는 것으로 보였으 며, 흔히 염증성 삼출물의 범위 밖으로 광범위한 망막외층 구 조들의 손실을 보였다(Fig. 2). 스테로이드를 이용한 치료로 이 러한 물질이 빠른 속도로 줄어들고, 외층망막의 구조는 이보다 는 느린 속도로 회복되는 것이 관찰되었다. 두 질환 모두 맥락막 에서 보이는 일관된 소견은 보이지 않았으나 일부의 급성 병변 에서는 다소의 맥락막 두께 증가를 보였으며, 스테로이드 치료 후에는 활동성 병변 아래 맥락막의 두께가 국소적으로 얇아지 는 경우도 있다고 하였다. 두 질환 모두 맥락막에서 보이는 일관 된 소견은 보이지 않았으나 일부의 급성 병변에서는 다소의 맥 락막 두께 증가를 보였으며, 스테로이드 치료 후에는 활동성 병 변 아래 맥락막의 두께가 국소적으로 얇아지는 경우도 있다고 하였다. 또 다른 최근 보고에 의하면 발생학적 이상소견으로 여 겨지던 국소 맥락막 함몰과 관련하여 중심 장액성 맥락막염과 같은 다른 맥락막 질환보다 $\mathrm{MCP} / \mathrm{PIC}$ 를 동반하여 관찰되는 비

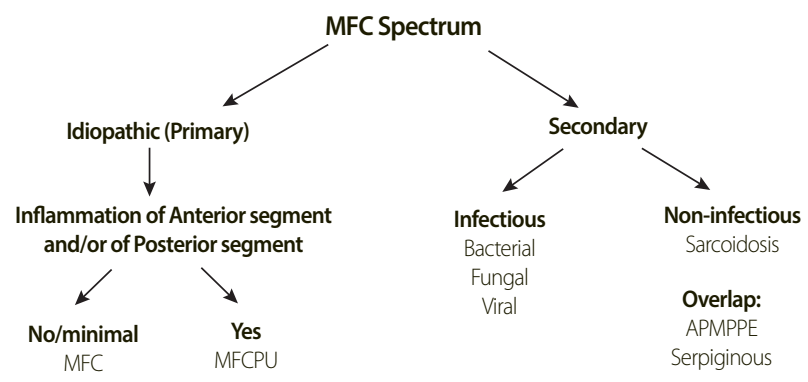

Figure 1. Spectrum of MFC. MFC = multifocal choroiditis; MFCPU = multifocal choroiditis and panuveitis; APMPPE = acute posterior multifocal placoid pigment epitheliopathy.

율이 높다 하였는데, 기존에 존재하던 "일차성” 국소 맥락막 함 몰 부위에 활동성 염증이 발생한 후 전형적인 MCP/PIC의 안저 변화를 보였던 증례를 보고함으로써 발생학적 이상소견으로 보
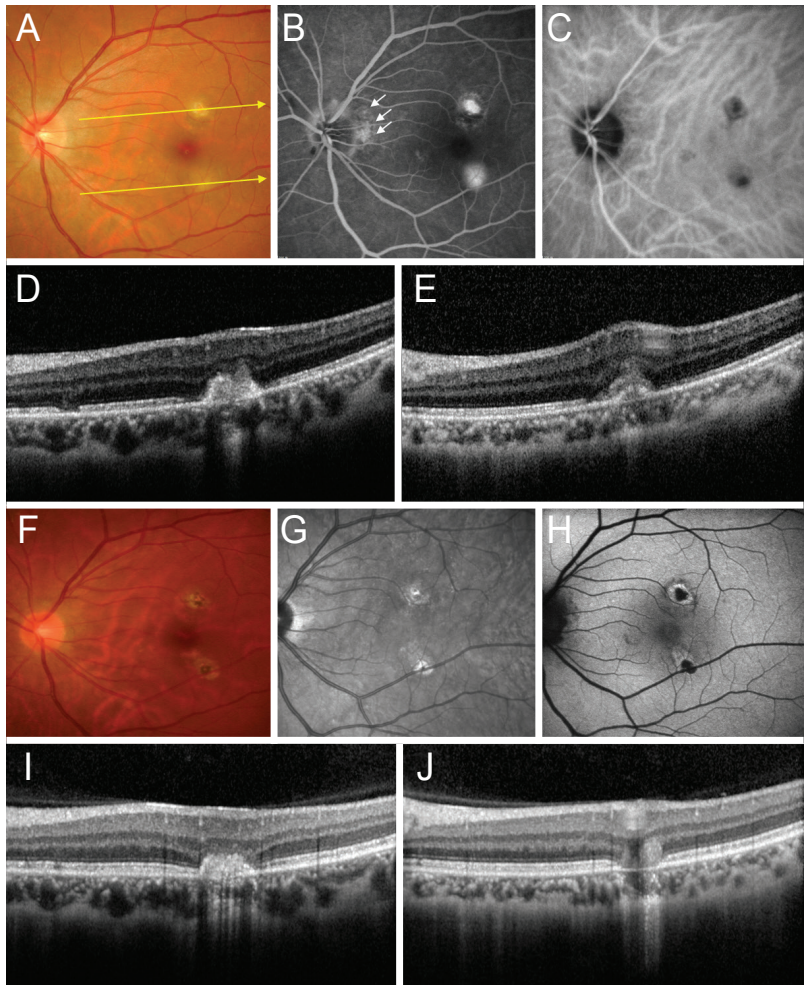

Figure 2. This 40-year-old myopic woman complained of paracentral scotoma in the left eye. The first and second rows (A-E) were obtained at baseline. (A) Note the small white spots at superior and inferior macular areas. There were no cells in the anterior chamber or vitreous cavity. (B) Late in the fluorescein angiogram, there was staining of the lesion. Peripapillary scarring was better visualized than on the color fundus photo (white arrows). (C) Late indocyanine green angiography revealed the hypofluorescent lesions. (D) Spectral domain optical coherence tomography section indicated by the upper yellow arrow of the color fundus photo showed a sub-retinal pigment epithelium (RPE) hyperreflective material infiltrating the subretinal space. (E) In the inferior section, the sub-RPE infiltration seemed to sprout into the outer retina, however, no clear choroidal involvement was detected in either lesions. The best-corrected visual acuity was 20/40. Two years from baseline (F-J): (F) Under the suspicion of choroidal neovascularization being present, the patient was treated with intravitreal bevacizumab. After 4 injections of anti-vascular endothelial growth factor, color fundus photo demonstrates pigmentary changes. (G) On infrared imaging, the pigmented scars of multifocal choroiditis lesions were seen as hyperreflective lesions. (H) Fundus autofluorescence showed hyperautofluorescence surrounding hypoautofluorescent central lesions. (I) The hyperreflective infiltration appeared to be regressed, and yet the sub-RPE lesion remained. (J) Note the flattening of the RPE abnormality, however, the indiscrete hyperreflective nodule remained obliterating the photoreceptor layers. The visual acuity was 20/60. 
이는 국소 맥락막 함몰도 실제로 무증상/비임상형의 국소 맥락 막 염증에 이차적으로 발생한 병변일 수 있다는 가설을 제시하 였다[11]. 흥미로운 것은 이들 병변들에서 주로 침범되는 부위가 현재 그들의 명칭과 부합하지 않는 망막색소상피하와 망막 외 층이라고 보고하였다. $\mathrm{MCP}$ 와 $\mathrm{PIC}$ 의 활동성 병변에서는 근본적 으로 같은 구조들이 같은 표현형으로 나타나고 같은 방법으로 치료하면 되기 때문에 둘을 구분하기 위한 노력이 큰 의미가 없 을 수 있다고 하였다. Multimodal imaging을 이용한 결과를 통 해서 이들 질환에 대한 병리학적 소견이나 정의, 그리고 명칭에 대해서 재평가가 필요하다고 결론 내리고 있다.

2014년 Fung et al. [12]은 41명 65안의 연속증례를 후향적으로 관찰 연구하였는데, 대상자로 다발성 맥락막염 병변을 보이면 서 앞포도막염이나 유리체 염증이 최소한 혹은 동반되지 않은 "idiopathic MFC" 환자들만 포함이 되었다. 그들의 multimodal imaging - 컬러 안저사진, 망막신경섬유층사진(red free photo), $\mathrm{FAF}, \mathrm{FA}, \mathrm{ICGA}, \mathrm{SD}-\mathrm{OCT}$-을 분석하여 임상적 특징과 진행 양상을 기술하고자 하였다. 진단시 평균연령은 38.4세(range: 15-81세)였으며 70.7\%의 환자가 여성이었다. 평균 굴절력은 -5.25 diopters (range: $+1.00 \sim-20.00$ )였으며, 평균시력은 첫 진 단 당시 20/46에서 92.6개월간의 평균 추적관찰 기간 후 20/42 로 약간 상승하였다. 60개월간 시력이 20/50 이하로 악화되지 않 은 생존율이 $100 \%$ 였다. 평균 92.6 개월의 추적관찰 기간 동안 크 기가 증가하거나 새롭게 발생한 맥락망막 반점이 약 $1 / 2$ 의 환자 에서 관찰되었으며, 재발하거나 새롭게 발생한 맥락막신생혈관 (choroidal neovascularization, CNV)이 1/3에서 관찰되었다. 60 개월간 $\mathrm{CNV}$ 없는 생존율은 $68.1 \%$ 였다. 첫 진단시에 약 반수에 서 양안성을 보였는데 이는 다른 대부분의 $\mathrm{MCP}$ 증례들에서 보 고되는 빈도보다는 낮은 것이다. 단안성으로 나타난 환자에서 $1 / 4$ 의 경우에는 60 개월 이내에 결국 양안으로 진행하였다. 과거 에는 전체포도막염이 동반되지 않은 질환에 대해서는 다른 질 환군으로 생각해야 한다는 주장들도 있었지만 실제로는 전형 적인 $\mathrm{PIC}$ 의 경우에도 전체포도막염이 동반된 증례가 보고된 적 이 있었던 것과 같이, 사실 $\mathrm{MFC}$ 와 $\mathrm{PIC}$, 그리고 전체포도막염 의 동반 유무에 관계없이 같은 질병의 스펙트럼으로 생각해야 할 것이다. 이러한 점에서 본 논문에서는 앞포도막염이나 유리 체염증이 동반되지 않은 MFC에 대하여 multimodal imaging을 통해 임상적인 양상과 특징들을 살펴보았는데, 처음엔 단안성 으로 나타났던 PIC와 비슷한 양상의 증례들이 시간이 지나면 서 결국엔 양안성으로 진행하거나 새로운 병변이 나타나는 등 의 경과를 보임을 확인하였다. 결국은 이들이 거의 비슷한 임 상양상을 보이는 한 질병의 스펙트럼 질환들임을 의미하는 것 이라고 생각한다.

2015년 Munk et al. [13]은 idiopathic MFC 중 특이한 유형의 환자들만을 선정하여 multimodal imaging-컬러 안저사진, 광 각 안저사진(wide-field color fundus image), FA, ICGA, SD-
OCT를 이용한 infrared (IR image)와 red-free short-wave blue $(488 \mathrm{~nm}) \mathrm{FAF}$, Optos를 이용한 green near-IR (787 nm) FAF, 그 외에 일부에서 전체망막전위도/다국소망막전위도-을 분석 하였는데, 이들은 후극부에 다발성 맥락막염 병변과 동시에 그 주위에 한 구역 및 다구역, 혹은 전반적인 외망막층/맥락망막 위축을 보였다[13]. 본 연구는 임상적으로 관찰되는 병변보다 횔 씬 광범위한 영역의 광수용체 기능이상으로 인해 급격한 시력 저하나 중심암점이 발생한 $\mathrm{MFC} / \mathrm{PIC}$ 증례들을 소개하였다. 그 리고 이런 변이형의 환자들은 치료 없이도 외망막층 및 시기능 의 완전한 회복부터 영구적 손실까지 다양한 임상결과를 보였 다. 첫 내원 시 환자들은 안전수지 및 안전수동의 극심한 시력 저하를 보이면서 시야암점을 호소하였는데, 이 부위는 OCT에 서 광수용체층이 희미해진 부분과 일치하였다(Fig. 3). 이런 변 화들은 주로 안저검사에서 관찰 가능한 맥락망막 병변에 인접 해 있었다. 또한, 이 부위는 FAF상 과형광으로 관찰되는데 그 기전은 정확히 알려져 있지 않다. 가장 가능성 있는 가설들로 활동성 염증에 의해 망막색소상피내 발광물질의 축적이 증가 해서이거나[14], 광수용체층의 파열이 시색소 물질의 저하로 연 결되어 빛 흡수능력이 떨어지면서 과형광을 띠게 되는 것이다 [15]. ICGA에서 판(plaque) 모양으로 관찰되는 저형광의 원인은 아직도 밝혀지지 않았는데, 맥락막 저관류, 맥락막 허혈, 또는 형광차단 효과 등이 가능한 원인들로 제시되었다. 활동성 염증 이 있을 때, OCT에서 ICGA의 저형광과 상응하는 부위의 헨레 층에서 고반사가 관찰되고 외망막층의 손상이 있는 곳에 맥락 막 두께가 두꺼워진 것을 고려해봤을 때 형광차단 효과 때문일 가능성이 가장 크다고 생각되고 있다[16]. 그들이 보고한 이전 연구에서는 이런 ‘변이형' 환자들 일부에서 광범위한 영역의 외 망막층/맥락망막 위축 병변이 시간에 따라 점점 더 진행한다고 하였으며, 중심시력은 질환의 말기까지 보존되는 경우가 많다 고 하였다[17]. 반면, 본 연구에서는 multimodal imaging을 통해 $\mathrm{MFC} / \mathrm{PIC}$ 환자들에서도 지속적인 시기능 손실이 가능하다는 것을 보여주었다. 염증반응의 정도에 따라 다양한 결과를 보일 수 있는데, 광수용체층 손상이 저절로 호전되거나 면역조절제 에 반응할 수 있으며, 최악의 경우 영구적일 수도 있다

\footnotetext{
고찰

White dot syndrome에 포함되는 질환군들 중에는 서로 매우 유사한 임상양상을 공유하기도 하고 때로는 한 환자에서 각각 의 개별적인 질환의 특징적인 임상양상이 동시에 혹은 순차적 으로 나타나는 경우들이 있다. 이들 질환군들을 비슷한 병태 생리를 가진 다양한 질환들로 볼 것이냐 혹은 한 가지 질환의 다양한 임상양상으로 볼 것이냐에 대한 개념에 대한 논의가 있 을 수 있다. 물론 아직은 이들 질환에 대한 치료가, 특히 각각의 질병별로, 개별적인 치료에 대한 개념이 확립되어 있지 않으므 로 현실적으로 큰 의미를 가지지 못한다고 생각할 수 있다. 하지
} 

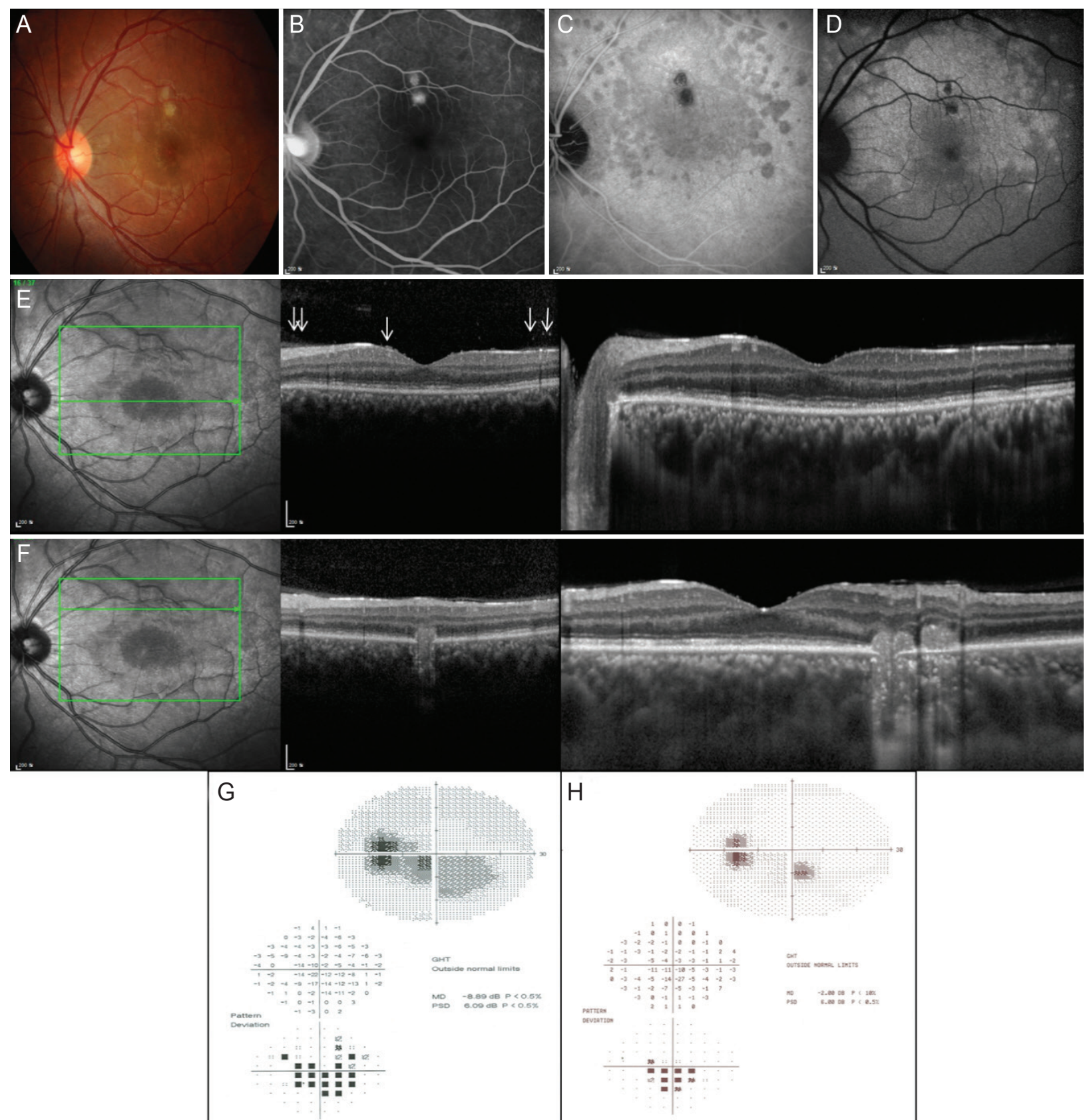

Figure 3. This 22-year-old man with myopia complained of central scotoma in the left eye right after suffering from upper respiratory infection. The best-corrected visual acuity was 20/60. (A) Color fundus photo revealed two large yellow chorioretinal lesions superior to the fovea. There were no cells in the anterior chamber or vitreous cavity ophthalmoscopically. (B) Fluorescein angiography demonstrated late staining of the chorioretinal lesions. (C, D) Indocyanine green angiography (ICGA) highlighted the hypofluorescent lesions but also had a plaque-like hypofluorescent area that corresponded to the hyperautofluorescent area seen with fundus autofluorescence, which outlined the ring-shaped hyperautofluorescence visible around the optic disc and the fovea. (E) Corresponding spectral domain optical coherence tomography (SD-OCT) showed attenuation of the external limiting membrane, inner segment/outer segment (IS/OS) and cone outer segment termination (COST) line adjacent to the chorioretinal lesions and where seemed to correspond to the hypofluorescent area on ICGA. The magnified inset showed the irregular photoreceptor layers in greater detail. There was no definite hyporeflectivity in the corresponding area on infrared imaging. There were inflammatory cells in the overlying vitreous (white arrows). (F) SD-OCT outlined the chorioretinal lesion visualized as a hyperreflective nodule, which broke through the retinal pigment epithelium disrupting the overlying retina. The adjacent outer retinal layers were not distinguishable. The magnified inset in the right showed the irregularity of the photoreceptor layers in greater detail. (G) The visual field (VF) defect corresponded to the area of hyperautofluorescence, where the IS/OS and COST lines were attenuated. $(H)$ Ten days later, the VF defect was much improved, however, no further imaging study was performed to verify this finding. The visual acuity was 20/30. 
만, 우리가 어떠한 질환에 대한 명칭과 개념을 명확히 하는 것 은 서로간의 단순한 소통에 있어서 뿐 아니라, 자연경과에 대한 관찰 혹은 향후 새로운 치료에 대한 연구를 진행하는 데 있어 서도 매우 중요하다고 생각된다.

그동안 $\mathrm{MFC} / \mathrm{PIC}$ 의 경우에 있어서는 그동안 제한된 진 단 방법과 다양한 임상양상으로 인하여, 오히려 개별 연구자 들이 매번 새로운 명칭들을 사용함으로써 혼란이 유발된 상 황으로 생각된다. PIC의 정의는 현재의 idiopathic MFC와 거 의 동일한데, 근 25 년간 $\mathrm{MFC}$ 보다 병변의 크기가 더 작고 후 극부에 군집되어 있는 경우로 그 의미가 좁혀졌었다[18]. 하지 만 2010년 Essex 등이 병변의 크기에 따라 임상양상에 차이 가 없다고 보고하면서 다시 기존의 포괄적인 정의를 사용하기 를 권장하였다[19]. "Pseudo-POHS"라는 용어는 Callanan and Gass [20]에 의해 처음 사용되었으며 Histoplasma의 풍토 지역 과 연관이 없으면서 $\mathrm{POHS}$ 와 비슷한 안저 변화를 보이는 질환 을 일컫는데, 이는 결국 $\mathrm{MFC}$ 와 같은 것으로 현재 널리 사용 되고 있지는 않다. "Multifocal inner choroiditis"는 두 가지의 의미를 갖는데, Krill 등은 POHS와 흡사한 안저병변과 $\mathrm{CNV}$ 가 있으면서 유리체염이 없고 histoplasmin skin test에 양성을 보인 군으로 정의한 반면[21], Scheider는 각각의 특징들을 단 독으로 갖고 있는 환자들을 한 집단으로 그룹화하기 위한 용 어로 사용하였다[22]. 각기 다른 뜻으로 같은 용어가 중복되 어 현재는 거의 사용되고 있지 않다. Morgan과 Schatz는 PIC, MFC with panuveitis (MCP), MFC with progressive subretinal fibrosis를 통틀어 “Recurrent multifocal choroiditis”라고 명명하 기를 제안하였는데 모두 현재 idiopathic MFC 안에 속하는 질 환들로 이 용어는 널리 받아들여지지 않았다[23]. "Multifocal choroidopathy"는 MFC/POHS-like 양상을 띠는 환자들을 전 부 포함하기 위한 포괄적인 용어로 제안되었으나 표현형이 비 슷하더라도 엄연히 다른 질환들이기에 같은 진단으로 분류하 는 것은 바람직하지 않다는 지적을 받았다[24]. "Disseminated inner choroiditis"는 프랑스인에서 histoplasma에 대한 노출 여 부에 상관없이 POHS-like 안저 변화를 보이는 경우로 정의하 였다. 이 환자들은 근대의 idiopathic MFC에 해당되며 현재 이 용어는 사용되고 있지 않다[25]. "Progressive subretinal fibrosis" 는 앞포도막염 및 유리체염이 일정치 않게 동반되면서 맥락막 병변과 망막하 섬유증이 관찰되는 질환이다. Idiopathic $\mathrm{MFC}$ 에 서 합병증으로 CNV가 발생할 수 있는데 progressive subretinal fibrosis가 이 과정의 공격적인 형태라고 보고 있다[26,27]. 유럽 의 젊은이들에게 발견되었던 POHS-like 안저 변화에 동반된 맥 락막신생혈관막을 "hemorrhagic maculopathy in young adults (macular choroidopathy)"라고 지칭하였는데, 이는 CNV가 합병 된 idiopathic MFC로 생각된다[28,29].

여기서 강조할 점은 hemorrhagic maculopathy in young adult, idiopathic CNV와 같이 $\mathrm{MFC} / \mathrm{PIC}$ 병변에 동반된 신생혈관과 같
은 합병증의 경우에 잘못 진단되는 경우가 흔히 있다는 것이다. 2011년에 Freund는 multimodal imaging을 통해 myopic CNV혹 은 idiopathic $\mathrm{CNV}$ 로 진단받았던 대다수의 케이스들이 실제로 는 $\mathrm{MFC}$ 였을 것이란 주장을 내세웠다[30]. 그보다 더 전인 2008 년에는 Machida et al. [31]이 idiopathic CNV가 염증성 맥락막 질환의 초기 증상일 가능성을 제시하였다. 실제로 $\mathrm{MFC} / \mathrm{PIC}$ 의 병변 부위에 신생혈관이 동반되는 경우가 흔하기 때문에 병변 을 명확히 구분하는 것은 쉽지 않지만, OCT상에서 확인되는 전 형적인 MFC/PIC 병변인 망막상피하 침윤에 대해서 그동안 신 생혈관으로 오해하는 경우가 드물지 않았던 것으로 생각된다. 이러한 병변의 경우 치료 없이도 혹은 스테로이드 등의 항염증 치료로 병변이 소실되고 망막색소상피가 회복되는 경우들이 있 는데, 특히 anti-vascular endothelial growth factor (VEGF)의 투여 후에 이러한 병변이 소실된 것을 약제에 의한 신생혈관치 료 효과로 오해하는 일들이 드물지 않았던 것으로 보인다. 하 지만, 만약 섬유혈관 조직인 신생혈관의 경우라면 주사치료 후 subretinal fibrosis/thickening과 같은 흥터조직이 남게 되겠지만 몇몇 idiopathic $\mathrm{CNV}$ 혹은 myopic CNV로 생각되어 anti-VEGF 치료를 했던 증례들 중 병변이 완전히 사라지고 망막색소상피 가 회복되는 경우들은 진단 자체에 오류가 있지 않았는지 확인 해볼 필요가 있다고 생각된다(Fig. 4).

앞서 소개한대로 Multimodal imaging 소견상 병변이 보이는 특징을 근거로 MFC/PIC는 명칭의 내용과는 다르게 맥락막 침 범은 거의 없으면서 망막색소상피하 침윤이 주된 병변이라는 주장이 제기되고 있다[10]. 또한, MEWDS를 포함한 몇몇 white dot syndrome에서도 이러한 imaging, 특히 OCT와 최근의 OCT angiography에서 관찰되는 소견을 근거로 외측 망막 혹은 망막 색소상피하에 국한된 병변이라는 주장이 제기되고 있다. 하지 만, 아직은 현재 imaging에서 보이는 맥락막의 음성소견(이상 없음)이 과연 신빙성이 있는지에 대한 검증이 필요할 것이며, 또 한 스펙트럼으로 나타나는 질환들에서 보이는 맥락막 변화를 어떻게 설명할 수 있을 것이냐 하는 등의 논란의 여지가 있다.

결론적으로, $\mathrm{MFC}$ 와 $\mathrm{PIC}$ 의 경우 최근 retinal imaging의 발 전으로 두 질병 간의 병변의 양상이 거의 같음을 확인할 수 있 었고 따라서 같은 질환으로 분류하는 것이 타당하다고 사료된 다. 또한 이러한 병변의 imaging상의 특징이 그동안 idiopathic $\mathrm{CNV}$ 혹은 myopic $\mathrm{CNV}$ 등으로 잘못 진단되었던 환자들에서 발견되는 경우들이 드물지 않다. 즉, 임상적으로 실제 MFC/PIC 의 빈도가 상당히 높음에도 불구하고 과소평가되었을 가능성 이 있다. 이렇게 retinal imaging의 발전은 기존에 비슷한 임상 양상으로 인하여 구분되지 못하였던 경우나, 혹은 오히려 같 은 질환군임에도 다양한 임상양상으로 인하여 다양한 질환으 로 오인되었던 경우에 있어서 질환의 정확한 진단과 개념 정립 에 기여하고 있다. 

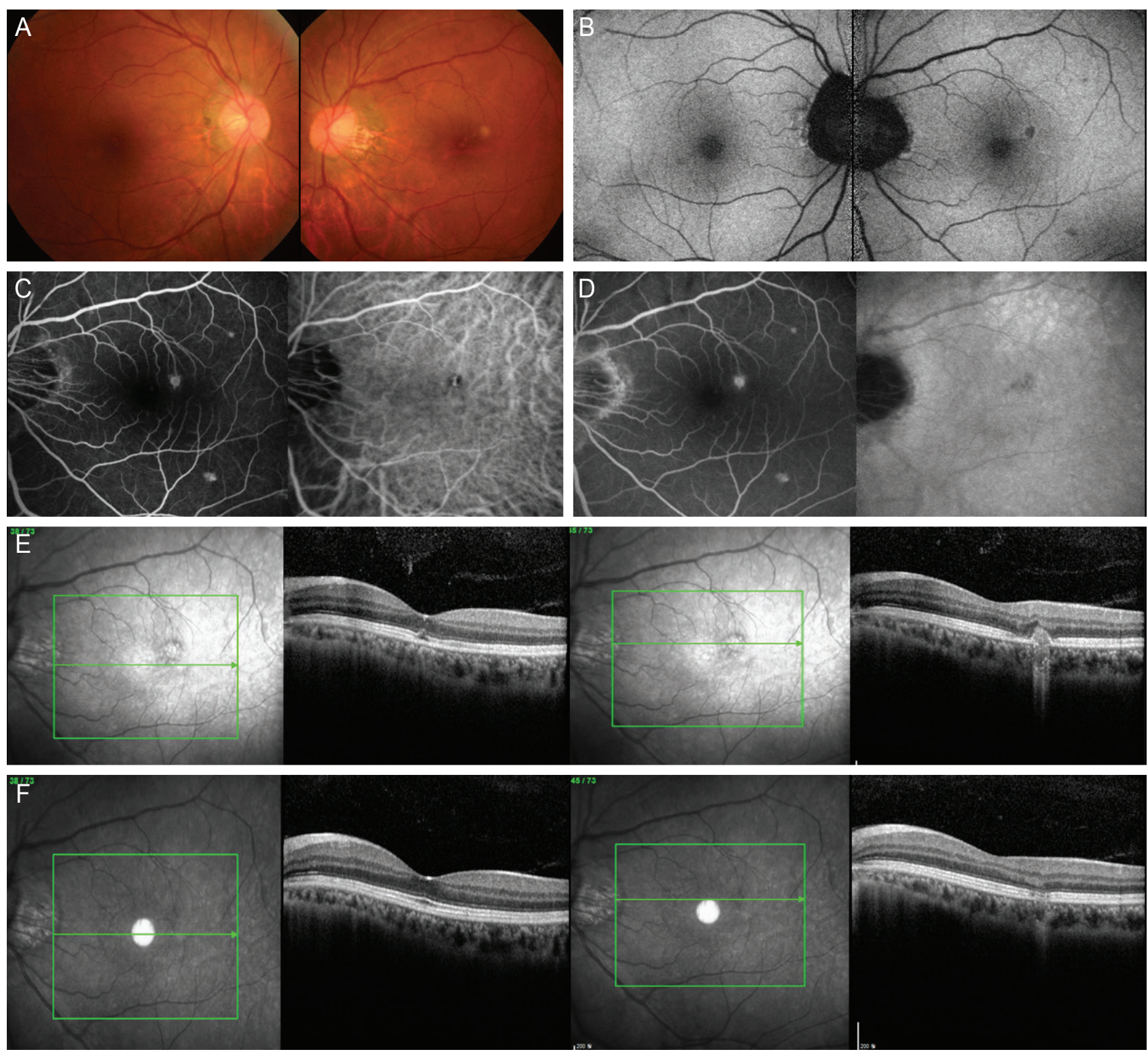

Figure 4. This 45-year-old myopic woman complained of blurred vision in the left eye. The first three rows (A-E) were obtained at baseline. (A) Color fundus photo revealed one small yellow chorioretinal lesion temporal to the fovea in the left eye. Both fundi showed peripapillary scarring equally. There were no cells in the anterior chamber or vitreous cavity ophthalmoscopically. (B) Fundus autofluorescence highlighted the hypofluorescent lesion in the left eye. (C, D) Fluorescein angiography showed staining of the chorioretinal lesions throughout all phases and mild late leakage. (E) On the left, spectral domain optical coherence tomography section crossing the fovea showed a slight elevation of the external limiting membrane, inner segment/outer segment and cone outer segment termination lines. On the right, the chorioretinal lesion was presented as a hyperreflective sub-retinal pigment epithelium infiltration invading the overlying retina. The visual acuity was 20/50. (F) Five months after treating with subtenon injection of triamcinolone, the elevation of the photoreceptor layers was relieved at the fovea and the chorioretinal lesion was completely resolved with mild irregularity of the outer retinal layers left. The visual acuity was 20/30.

\section{Conflicts of Interest}

There are no conflicts of interest.

\section{References}

1. Nozik RA, Dorsch W. A new chorioretinopathy associated with anterior uveitis. Am J Ophthalmol 1973;76:758-62.

2. Dreyer RF, Gass DJ. Multifocal choroiditis and panuveitis. A syn- 
drome that mimics ocular histoplasmosis. Arch Ophthalmol 1984;102:1776-84.

3. Watzke RC, Packer AJ, Folk JC, et al. Punctate inner choroidopathy. Am J Ophthalmol 1984;98:572-84.

4. Taira K, Nakazawa M, Takano Y, Ota T. Acute zonal occult outer retinopathy in the fellow eye 5 years after presentation of punctate inner choroidopathy. Graefes Arch Clin Exp Ophthalmol 2006;244:880-2.

5. Atan D, Fraser-Bell S, Plskova J, et al. Punctate inner choroidopathy and multifocal choroiditis with panuveitis share haplotypic associations with IL10 and TNF loci. Invest Ophthalmol Vis Sci 2011;52:3573-81.

6. Haen SP, Spaide RF. Fundus autofluorescence in multifocal choroiditis and panuveitis. Am J Ophthalmol 2008;145:847-53.

7. Gass JD, Agarwal A, Scott IU. Acute zonal occult outer retinopathy: a long-term follow-up study. Am J Ophthalmol 2002;134:329-39.

8. Holz FG, Kim RY, Schwartz SD, et al. Acute zonal occult outer retinopathy (AZOOR) associated with multifocal choroidopathy. Eye (Lond) 1994;8(Pt 1):77-83.

9. Tiedeman JS. Epstein-Barr viral antibodies in multifocal choroiditis and panuveitis. Am J Ophthalmol 1987;103:659-63.

10. Spaide RF, Goldberg N, Freund KB. Redefining multifocal choroiditis and panuveitis and punctate inner choroidopathy through multimodal imaging. Retina 2013;33:1315-24.

11. Kim H, Woo SJ, Kim YK, et al. Focal choroidal excavation in multifocal choroiditis and punctate inner choroidopathy. Ophthalmology 2015;122:1534-5.

12. Fung AT, Pal S, Yannuzzi NA, et al. Multifocal choroiditis without panuveitis: clinical characteristics and progression. Retina 2014;34:98-107.

13. Munk MR, Jung JJ, Biggee K, et al. Idiopathic multifocal choroiditis/punctate inner choroidopathy with acute photoreceptor loss or dysfunction out of proportion to clinically visible lesions. Retina 2015;35:334-43.

14. Schmitz-Valckenberg S, Holz FG, Bird AC, Spaide RF. Fundus autofluorescence imaging: review and perspectives. Retina 2008;28:385-409.

15. Freund KB, Mrejen S, Jung J, et al. Increased fundus autofluorescence related to outer retinal disruption. JAMA Ophthalmol 2013;131:1645-9.

16. Chen SN, Hwang JF. Ocular coherence tomographic and clinical characteristics in patients of punctuate inner choroidopathy associated with zonal outer retinopathy. Ocul Immunol Inflamm 2014;22:263-9.

17. Jung JJ, Khan S, Mrejen S, et al. Idiopathic multifocal choroiditis with outer retinal or chorioretinal atrophy. Retina 2014;34:143950.

18. Amer R, Lois N. Punctate inner choroidopathy. Surv Ophthalmol 2011;56:36-53.

19. Essex RW, Wong J, Fraser-Bell S, et al. Punctate inner choroidopathy: clinical features and outcomes. Arch Ophthalmol 2010;128:982-7.

20. Callanan D, Gass JD. Multifocal choroiditis and choroidal neovascularization associated with the multiple evanescent white dot and acute idiopathic blind spot enlargement syndrome. Ophthalmology 1992;99:1678-85.

21. Krill $A E$, Chishti MI, Klien BA, et al. Multifocal inner choroiditis. Trans Am Acad Ophthalmol Otolaryngol 1969;73:222-45.

22. Scheider A. Multifocal inner choroiditis. Ger J Ophthalmol 1993;2:1-9.

23. Morgan CM, Schatz H. Recurrent multifocal choroiditis. Ophthalmology 1986;93:1138-47.

24. Ongkosuwito JV, Kortbeek LM, Van der Lelij A, et al. Aetiological study of the presumed ocular histoplasmosis syndrome in the Netherlands. Br J Ophthalmol 1999;83:535-9.

25. Saraux H, Pelosse B, Guigui A. Multifocal inner choroiditis: pseudohistoplasmosis. The European form of the presumed American histoplasmosis. J Fr Ophtalmol 1986;9:645-51.

26. Cantrill HL, Folk JC. Multifocal choroiditis associated with progressive subretinal fibrosis. Am J Ophthalmol 1986;101:170-80.

27. Palestine AG, Nussenblatt RB, Parver LM, Knox DL. Progressive subretinal fibrosis and uveitis. Br J Ophthalmol 1984;68:667-73.

28. Flage $T$, Sand AB, Syrdalen P. Haemorrhagic maculopathy in young adults. Acta Ophthalmol (Copenh) 1977;55:489-96.

29. Bottoni FG, Deutman AF. Idiopathic sub-retinal neovascular membranes in the macula (hemorrhagic macular choroidopathy of young adults). Clinical report and effectiveness of laser treatment. Doc Ophthalmol 1986;64:311-43.

30. Vance SK, Khan S, Klancnik JM, Freund KB. Characteristic spectral-domain optical coherence tomography findings of multifocal choroiditis. Retina 2011;31:717-23.

31. Machida S, Fujiwara T, Murai K, et al. Idiopathic choroidal neovascularization as an early manifestation of inflammatory chorioretinal diseases. Retina 2008;28:703-10. 


\section{국문초록}

\section{Multimodal imaging을 통한 다초점맥락막염과 점상내측맥락막병증의 비교, 그리고 그 정의에 대한 고찰}

'Multifocal choroiditis (MFC)'는 주로 근시를 가진 젊은 여성에서 다초점의 맥락막 염증병변이 발생하는 질환으로 정의되어 왔다. 이 용어는 원래 특발성으로 발생하는 경우를 지칭하지만 유사한 망막소견을 보이는 "Punctate inner choroidopathy (PIC)" 및 여러 가 지 감염성 질환들에서 여러 연구자들이 사용한 다양한 병명들은 $\mathrm{MFC}$ 를 이해하는 데 혼란을 주고 있다. 현재 많은 저자들이 안구내 염증 반응 유무에 관계없이 MFC와 PIC를 같은 스펙트럼 질환이라고 보고 있으며, “idiopathic MFC"라는 포괄적인 개념의 진단명으로 묶 어 사용하고 있다. 또한 imaging상 병변의 특징이 기존에 idiopathic choroidal neovascularization (CNV) 혹은 myopic CNV 등으로 진단되었던 환자들에서 드물지 않게 발견되면서, 임상적으로 실제 $\mathrm{MFC/PIC}$ 의 빈도가 과소평가되었을 가능성도 제시되었다. 이렇게 Retinal imaging 의 발전은 기존에 비슷한 임상양상으로 인하여 구분되지 못하였던 경우나, 혹은 오히려 같은 질환군임에도 다 양한 임상양상으로 인하여 다양한 질환으로 오인되었던 경우에 있어서 질환의 정확한 진단과 개념 정립에 기여하고 있다. 